\title{
Development of craft Beer with pecan shell aqueous extract [(Carya illinoensis) (Wangenh) C. Koch]
}

\section{Desenvolvimento de cerveja artesanal com extrato aquoso de casca de noz-pecã [(Carya illinoensis) (Wangenh) C. Koch $]$}

\author{
Gabriela Suthovski ${ }^{1}$, Rúbia Corassa ${ }^{1}$, Thiago Okagawa Silva ${ }^{1}$, Carine Priscila Silva ${ }^{1}$, Jucieli \\ Weber ${ }^{1}$, André Lazarin Gallina ${ }^{2}$, Letiére Cabreira Soares ${ }^{1}$, Everton Pizatto ${ }^{1}$, Carlos Eduardo \\ Cereto $^{1}$, Camila Dalmolin ${ }^{1}$, Fernanda Oliveira Lima ${ }^{1 *}$, Dalila Moter Benvegnú ${ }^{1}$
}

\begin{abstract}
Different ingredients and adjuncts have been used in the production of craft beer aiming to add new characteristics to the final product. In turn, the pecan nut has recognized antioxidant properties and, therefore, the extract of its shell was added in the beer production process with the main objective of increasing the beer antioxidant capacity. The all-grain method was used to produce the beverage and, on the packaging step, pecan nutshell extract was added at three different concentrations. The samples underwent antioxidant, physicochemical, and sensorial analysis. Data were submitted to analysis of variance (ANOVA). The use of pecan nutshell extract as an ingredient in beer processing has proved to be a viable alternative due to satisfactory results in sensory evaluation, with good acceptability of the consumers, maintaining physicochemical characteristics similar to the standard beer produced without the extract. However, the addition of the extract did not increase the antioxidant capacity in craft beer. Even though the antioxidant power of produced beer wasn't increased in this experiment, still pecan nutshell could be a good resource of antioxidants to whom drink beer, and your low price in the market make it viable to beer industry.
\end{abstract}

Keywords: antioxidant; alcoholic beverage; byproduct; nutshell, sensorial analysis

\section{RESUMO}

Diferentes ingredientes e adjuvantes têm sido utilizados na produção de cervejas artesanais com o objetivo de agregar novas características ao produto final. Por sua vez, a noz-pecã possui reconhecidas propriedades antioxidantes e, portanto, o extrato de sua casca foi adicionado no processo de produção da cerveja com o objetivo principal de aumentar a capacidade antioxidante da cerveja. O método all-grain foi usado para produzir a bebida e, na etapa de embalagem, o extrato de casca de noz-pecã foi adicionado em três concentrações diferentes. As amostras foram submetidas a análises antioxidantes, físico-químicas e sensoriais. Os dados foram submetidos à análise de variância (ANOVA). A utilização do extrato de casca de noz-pecã como ingrediente no processamento de cerveja tem se mostrado uma alternativa viável devido aos resultados satisfatórios na avaliação sensorial, com boa aceitabilidade pelos consumidores, mantendo características físico-químicas semelhantes às da cerveja padrão produzida sem o extrato. Porém, a adição do extrato não aumentou a capacidade antioxidante da cerveja artesanal. Mesmo que o poder antioxidante da cerveja produzida não tenha aumentado neste experimento, ainda a casca de noz-pecã pode ser um bom recurso de antioxidantes para quem bebe cerveja, e seu baixo preço no mercado a torna viável para a indústria cervejeira.

\footnotetext{
${ }^{1}$ Universidade Federal da Fronteira Sul.*E-mail: fernanda.lima@uffs.edu.br

${ }^{2}$ Universidade Estadual do Centro-Oeste.
} 


\section{INTRODUÇÃO}

Beer is an alcoholic and carbonated beverage, originated from yeast fermentation of barley malt sugars (HUMIA et al., 2019). Worldwide appreciated, beer is nowadays the third most consumed drink in the world, and Brazil gains importance in this market once it figures in the hall of the four largest beer producers, following China, the US and Germany. Part of that success occurs because of beer popularity, which is intensely present in all social strata. Concomitantly to its popularization, a market segmentation movement is observed due to the rise of a more refined appreciation. The consumers search for special flavors, allied to beneficial health components and low alcohol content, encouraging the production of variated beer formulations in order to satisfy these specific consumers (BRASIL, 2016; MARTINEZ-GOMEZ; CABALLERO; BLANCO, 2020).

The segmentation of beer market starts in the beer type produced. The usual preparation takes barley malt, hop, yeast and high-quality water. In addition to these components, sometimes it is possible to use other adjuncts such as rice, corn and wheat (MARTINEZ-GOMEZ; CABALLERO; BLANCO, 2020). To obtain an adequate and balanced beer, it is necessary to follow a $50 \%$ or higher proportion of barley malt weight as a sugar source in the primitive extract. The proportion of ingredients may vary according to the beer style, as well as the yeast chosen (HUMIA et al., 2019; SIQUEIRA, P. BOLINI, H. MACEDO, 2009).

In this context, it is possible to classify beer into two main groups: Ales and Lagers. The main group differences lie in the fermentation conditions and the type of yeast used. Lagers are the result of Saccharomyces pastorianus fermentation, which occurs below $12^{\circ} \mathrm{C}$ (HOLT et al., 2018; HUMIA et al., 2019). Among the Lager beers, the most well-known style is Pilsen, which was originated in the Czech Republic. It is a softer variation of this style and the most industrially produced type of beer today, as well as the most spread around the world (ZUPPARDO, 2010). Ale beers are the most consumed beer in northern countries, such as Canada, Germany, and Belgium. It is called high fermenting beer, originated from Saccharomyces cerevisiae fermentation at higher temperatures (generally between $18^{\circ} \mathrm{C}$ to $25^{\circ} \mathrm{C}$ ), and it usually shows an increased amount 
of antioxidant compounds when compared to the Lager family (HUMIA et al., 2019; KOREN et al., 2019; MARTINEZ-GOMEZ; CABALLERO; BLANCO, 2020).

Antioxidants are interesting compounds, once their activity may bring health benefits. These molecules can interact with oxygen and nitrogen reactive species (ROS/RNS) naturally generated in the human organism. In excess, ROS/RNS may damage cellular structures and contribute to pathological processes. Antioxidants act by donating electrons to these reactive species, stabilizing them, and preventing the reaction of these with others from the organism, avoiding its harmful effect (ATANASOV et al., 2018; KOREN et al., 2019; MARTINEZ-GOMEZ; CABALLERO; BLANCO, 2020). Since the antioxidant activity is interesting due to its health benefits, adding ingredients with high antioxidants content to beer formulation may enrich the beverage and bring benefits to those consuming it (ATANASOV et al., 2018; HOLT et al., 2018; HUMIA et al., 2019; MARTINEZ-GOMEZ; CABALLERO; BLANCO, 2020).

One possible antioxidant adjunct to be used in handmade beers is the pecan nutshell extract (Carya illinoensis). Pecan nut contains thiamine, folate, vitamin B6, and minerals such as calcium, iron, and is zinc-rich, besides its antioxidant potential, demonstrated by large phenolic and condensed tannin compounds (ATANASOV et al., 2018). In seed processing, nuts are separated from the shell, which is considered an industrial reject, representing between $40 \%$ to $50 \%$ of the discarded material (VILLARREAL-LOZOYA; LOMBARDINI; CISNEROS-ZEVALLOS， 2007; WORLEY, 1994). However, the pecan nutshell is a rich antioxidant compound, as it is easily possible to find large amounts of phenolic and condensed tannins in its constitution, sometimes even larger than in the nut itself (ATANASOV et al., 2018; BENVEGNÚ et al., 2013; VILLARREAL-LOZOYA; LOMBARDINI; CISNEROS-ZEVALLOS, 2007; WORLEY, 1994).

The pecan nutshell can be boiled in water and the resulting pecan shell aqueous extract (PSAE) is popularly used in inflammatory and oxidative conditions, diabetes, obesity, hypercholesterolemia, and hepatotoxicity prevention, as well as cancer. These effects were already confirmed by many researches (BENVEGNÚ et al., 2010, 2013; DAI; MUMPER, 2010; DE LA ROSA; ALVAREZ-PARRILLA; SHAHIDI, 2011; HILBIG et al., 2018; PORTO et al., 2013; PRADO et al., 2013; VILLARREALLOZOYA; LOMBARDINI; CISNEROS-ZEVALLOS, 2007). 
Therefore, the objective of this study is to incorporate the PSAE into a handmade beer, improving its antioxidant capacity, and providing an alternative enriched formula that maintain its physicochemical and sensory aspects.

\section{MATERIAL AND METHODS}

\section{Location}

The research was conducted after the approval of the Ethics Committee (protocol $\mathrm{n}^{\mathrm{o}}$ 62078316.4.0000.5564) of Federal University of South Frontier (UFFS). The pecan shells were donated by Pecantea (Cachoeira do Sul, Rio Grande do Sul, Brazil).

\section{Extract Processing}

The preparation of the raw pecan shell aqueous extract (PSAE) followed the method described by Benvegnú et al. (2010) and three concentrations of the same extract were used (5\%, 10\% and 15\%) (BENVEGNÚ et al., 2013). The ready-to-use extracts were stored in amber bottles until its addition to the beer. The extracts preparation occurred concomitantly with the beer maturation.

\section{Beer Processing}

The brewed craft beer was framed within the Oatmeal Stout style, an Ale beer, according to the characteristics presented in the Beer Judge Certification Program (BJCP, 2015). The ingredients and basic formulation used to produce the beer are described in Table 1.

Table 1 - Ingredients and basic formulation for the production of 20 liters of Oatmeal Stout craft beer.

\begin{tabular}{c|c|c}
\hline Quantity (kg) & Component & Type \\
\hline 4.00 & Pale Ale Malt & Grain \\
\hline 0.50 & Flaked Oat & Grain \\
\hline 0.25 & Coffee Malt & Grain \\
\hline 0.25 & Chocolate Malt & Grain \\
\hline 0.023 & Hallertau Magnum & Hop \\
\hline 0.01150 & SafAle S-04 & Yeast \\
\hline
\end{tabular}


The malt selection was composed of Pale Ale (80\%) and equal amounts (5\%) of Coffee and Chocolate malt, besides the addition of oat flakes (10\%) as an adjunct. All mashing conditions were defined with the help of BeerSmith2 Software. The calculations of water amount considered its loss along the process (grains absorption, boil evaporation, hot trub, liquid contraction when cooling, and cold trub). The mashing was carried out in stainless steel tanks with a perforated cylinder filter and heated with LP gas. In this tank, the mixture of malts, flaked oats, and $17.5 \mathrm{~L}$ of water underwent three different temperature and time steps. The first step was carried out at $50{ }^{\circ} \mathrm{C}$ for $15 \mathrm{~min}$ for protease activation, the second one at $66.7^{\circ} \mathrm{C}$ for $60 \mathrm{~min}$ for $\alpha$ - and $\beta$-amylase saccharification, and the last one at $75.6^{\circ} \mathrm{C}$ for $10 \mathrm{~min}$ for enzyme inactivation. At the end of these steps, the primary wort was obtained.

Subsequently, the primary wort was filtrated and separated from malt and oat residues by filtration. The residues were washed with $15.6 \mathrm{~L}$ of water at $75^{\circ} \mathrm{C}$ and, upon end of washing, the secondary wort was obtained and mixed to the primary wort. The resulting wort underwent a 60-min boil, and 23g of Hallertau Magnum hop was added at the beginning of the boil. When the boil ended, the wort was rapidly cooled down to 23 ${ }^{\circ} \mathrm{C}$ using a copper heat exchanger and transferred to a fermenter. In the fermenter, Saccharomyces cerevisiae yeast (SafAle S-04, Fermentis®) previously hydrated was added and the container accommodated in a BOD incubator (Biochemical Oxygen Demand) at $18{ }^{\circ} \mathrm{C}$. Primary fermentation lasted 4 days at $18{ }^{\circ} \mathrm{C}$ and the secondary one lasted 7 days, rising $1^{\circ} \mathrm{C}$ by day until it reached $24^{\circ} \mathrm{C}$. After the two fermentation steps, beer was cooled down to $8{ }^{\circ} \mathrm{C}$ for 7 days for maturation and then maintained at $3{ }^{\circ} \mathrm{C}$ for 3 days to final cold crash. The bottling was done into $300-\mathrm{mL}$ amber glass bottles. In the bottles, $50 \mathrm{~mL}$ of PSAE was directly added at three different concentrations $(5 \%, 10 \%$, and $15 \%$ ) together with $6 \mathrm{~g} / \mathrm{L}$ of sucralose. The bottle fermentation lasted 10 days at room temperature $\left(23^{\circ} \mathrm{C}\right)$.

\section{Beer Physicochemical Analysis}

All brewed beers were analyzed according to the Physicochemical Methods for Food Analysis Guidelines and conducted in triplicate with decarbonated samples (ZENEBON, PASCUET, TIGLEA, 2008). The hydrogenionic potential (pH), total acid, residual ashes, density, and alcohol content assays were performed. 


\section{Hydrogenionic Potential (pH) Determination}

To determine the $\mathrm{pH}, 50 \mathrm{~mL}$ of each sample was transferred to a $100 \mathrm{~mL}$ beaker. The $\mathrm{pH}$ meter electrode (Tecnopon $\left.{ }^{\circledR}\right)$ were washed with bidistilled and deionized water, then dried, and immersed in the sample. The sample was maintained under stirring and $\mathrm{pH}$ value was set when it was stable in the PH meter (ZENEBON, PASCUET, TIGLEA, 2008).

\section{Total Acidity Determination}

For total acid determination, $50 \mathrm{~mL}$ of each sample was transferred into a $100-\mathrm{mL}$ Erlenmeyer flask containing $500 \mu \mathrm{L}$ of phenolphthalein. The acids were neutralized by the addition of a $\mathrm{NaOH} 0.1 \mathrm{M}$ standard solution. The standard solution was added to the sample until the turning point when a pink color was observed. The total acidity was expressed as $\mathrm{g}$ of acetic acid in $100 \mathrm{~mL}$ of sample (ZENEBON, PASCUET, TIGLEA, 2008).

\section{Residual Ashes}

The residual ashes assay demonstrates the number of inorganic substances in the sample. Five or $10 \mathrm{~g}$ of the liquid samples were weighted and kept in water-bath, until evaporation. Then, residues of samples were conditioned in previously prepared porcelain capsules and conducted to a muffle at $550{ }^{\circ} \mathrm{C}$ until total coal elimination. After cooling the desiccator, the residual ashes were weighed in an analytical balance. The residual ashes are referred to as the percentage of mass relative to total mass weighted in the process beginning (ZENEBON, PASCUET, TIGLEA, 2008).

\section{Density}

The density analysis was performed with a pycnometer. The pycnometer was washed and rinsed with absolute ethanol (99.9\%, P.A.) and dimethyl ether (DME), then dried and weighted. The pycnometer was filled with water at $20^{\circ} \mathrm{C}$ and weighed again. The same pycnometer was washed, dried, and filled with the sample. The density was calculated as the sample and water weights ratio minus the weight of the empty pycnometer (ZENEBON, PASCUET, TIGLEA, 2008). 


\section{Alcohol Content}

To calculate the alcohol content by weight, the distilled sample was measured in an alcoholmeter (ZENEBON, PASCUET, TIGLEA, 2008).

\section{Antioxidants Analysis of Beers}

The antioxidant activity was determined using the free radical DPPH (2,2diphenyl-1-picrylhydrazyl) consumption, according to the method described by Freitas et al. (2009). The absorbance decay was measured after 30- and 60-min reaction time at 515 $\mathrm{nm}$ wavelength. The calibration curve was plotted as a function of the percentage of DPPH radical scavenging activity versus Trolox concentration. The results are expressed as mmol/L Trolox eq (FREITAS et al., 2009).

\section{Sensory Analysis}

The sensory analysis measured consumer preferences. To perform this evaluation, 60 non-trained participants aged 18 or over firstly signed a Commitment Term informing them about the study. Then, $50 \mathrm{~mL}$ of each beer sample containing different PSAE concentrations were served to the participants in plastic glasses. In the window between one beer sample to the other, a glass of mineral water was given to avoid residual taste between samples. After each sample taste, participants reported sensorial characteristics in a chart, such as color, aroma, flavor, and global appreciation on a structured 9-point hedonic scale (9-liked it very much; 8 - really liked it; 7 - liked it moderately; 6 - liked it a little; 5 -neither liked nor disliked; 4 -disliked it a little; 3 -disliked it moderately; 2 - really disliked it; 1 - dislike it very much) (DUTCOSKY, 2011).

\section{Statistical Analysis}

For physicochemical analysis, samples from three bottles, each containing one extract concentration, were analyzed. Statistical analyses were performed in STATISTIC (version 8.0) software and reported as mean \pm standard deviation (SD). For hydrogenionic potential $(\mathrm{pH})$, total acid, residual ashes, density, alcohol content, and antioxidant assays, a one-way ANOVA and a Tukey-Kramer post-hoc test were conducted to assess the significance of the results obtained. For sensory analysis, a one-way ANOVA test was performed. In both cases, a $5 \%$ significance level $(\mathrm{p}<0.05)$ was adopted. 


\section{RESULTS AND DISCUSSION}

The physicochemical analysis results of beers in each PSAE concentration are presented in Table 2.

Table 2 - Physicochemical analysis results of the craft beer with Pecan Shell Aqueous Extract (PSAE).

\begin{tabular}{c|c|c|c|c|c}
\hline $\begin{array}{c}\text { Concentration } \\
\text { of PSAE }\end{array}$ & $\mathrm{pH} \pm \mathrm{SD}$ & $\begin{array}{c}\text { Alcoholic } \\
\text { content } \pm \mathrm{SD} \\
(\% \text { vol. })\end{array}$ & $\begin{array}{c}\text { Ashes } \pm \mathrm{SD} \\
(\mathrm{g} \%)\end{array}$ & Acidity $\pm \mathrm{SD}$ & $\begin{array}{c}\text { Density } \pm \mathrm{SD} \\
(\mathrm{g} / \mathrm{L})\end{array}$ \\
\hline $0 \%(\mathrm{n}=3)$ & $4,27 \pm 0,10^{\mathrm{a}}$ & $5,0^{\mathrm{a}}$ & $0.21 \pm 0.02^{\mathrm{a}}$ & $1.26 \pm 0.16^{\mathrm{a}}$ & $1.0081 \pm 0.0002^{\mathrm{a}}$ \\
\hline $5 \%(\mathrm{n}=3)$ & $4,25 \pm 0,29^{\mathrm{a}}$ & $5,0^{\mathrm{a}}$ & $0.23 \pm 0.03^{\mathrm{a}}$ & $1.12 \pm 0.19^{\mathrm{a}}$ & $1.0084 \pm 0.0002^{\mathrm{a}}$ \\
\hline $10 \%(\mathrm{n}=3)$ & $4,29 \pm 0,23^{\mathrm{a}}$ & $5,0^{\mathrm{a}}$ & $0.24 \pm 0.03^{\mathrm{a}}$ & $1.19 \pm 0.33^{\mathrm{a}}$ & $1.0087 \pm 0.00008^{\mathrm{a}}$ \\
\hline $15 \%(\mathrm{n}=3)$ & $4,49 \pm 0,14^{\mathrm{a}}$ & $5,0^{\mathrm{a}}$ & $0.21 \pm 0.02^{\mathrm{a}}$ & $1.04 \pm 0.05^{\mathrm{a}}$ & $1.0084 \pm 0.00016^{\mathrm{a}}$ \\
\hline
\end{tabular}

* Equal letters in the same column indicate no statistical differences. All analyses were performed in triplicate.

Hydrogenionic potential $(\mathrm{pH})$ is an important characteristic of beer, because it determines if the beverage is within the proposed style (BJCP, 2015). The addition of the extract did not result in significant changes in $\mathrm{pH}$, so it remained within the expected standards for the style. According to Compton (1978), $\mathrm{pH}$ values may range between 3.8 to 4.7 to be considered adequate to a beer. The production of organic acids during alcoholic fermentation is responsible for the $\mathrm{pH}$ decrease between wort and the beer (COMPTON, 1978; REINOLD, 1997). Our result shows that even with the increment of PSAE to beer formula at four different concentrations, $\mathrm{pH}$ values remained constant, revealing an adequate beer formula.

The alcoholic content of beer samples was approximately 5\%. According to Brazil (2016), beverages with alcohol content between 4.5 to $7.0 \%$ are classified as "medium alcoholic content" (BRASIL, 2016). The alcoholic content is related to wort characteristics such as soluble solids quantities because the more solids are consumed by yeast, the more alcohol is produced, decreasing the amount of soluble solids suspended in the liquid (BOTELHO, 2006). Our initial and final density of the wort were, respectively, 1.052 and $1.015 \mathrm{~g} / \mathrm{L}$, generating the alcohol content described above. 
High ash content is directly related to density due to the concentration of particles in substance (ZENEBON, PASCUET, TIGLEA, 2008). The amount of ashes found at all PSAE beer concentrations is in compliance with the recommendations, as this value cannot exceed the decimal values of centesimal composition, generally between 2.5 and $4.5 \%$ of residuals. In brewing, residuals such as yeast, fibers, hemicellulose, and other organic and inorganic compounds accumulate and generate turbidity on the final liquid, which compromises the appearance, and must be discarded (ROBERTSON et al., 2010; MATHIAS, MELLO, SERVULO, 2014). Therefore, an adequate beer should have a minimum water percent of $95 \%$, characteristic necessary to produce a good-looking and palatable drink (BJCP, 2015)

The organic acids generated as byproducts of beer fermentation are closely related to the acid content in beer (TECHAKRIENGKRAI et al., 2004). To determine the acidity, the amount of titratable total organic acids in the liquid must be quantified, and in our results, this amount did not vary with the PSAE content increase, indicating a good result for this parameter.

Regarding the addition of PSAE, the concentrations of disperse elements such as fibers, proteins, and amino acids could alter the density values. Our beer density values varied within $1.0081 \mathrm{~g} / \mathrm{L}$ (0\% of PSAE) and $1.0087 \mathrm{~g} / \mathrm{L}$ (15\% of PSAE), densities similar to water, and there was no significant difference between formulations, demonstrating that the extract addition is not sufficient to increase liquid density.

Despite the beer antioxidant capacity related to PSAE concentration, the greater the beer's antioxidant activity, the higher is the DPPH consumption. In our results, no statistical differences were observed between samples, since the content of PSAE did not modify the antioxidant capacity of the brewed handmade beer (Table 3). DPPH evaluation is a simple method, but it has some limitations. A study performed by Tafulo et al. (2010) demonstrates that the lowest values of antioxidant content were obtained with the DPPH method (TAFULO et al., 2010). Antioxidants reacting with peroxide radicals may show a slow reaction to DPPH. Considering that the DPPH method is based on a kinetic reaction, the DPPH consumption rate is decreased, which generates low or no significant results. This fact could explain why we did not observe significant statistical differences in our study. 
Table 3 - Antioxidant content analysis of handmade beer with Pecan Shell Aqueous Extract (PSAE).

\begin{tabular}{c|c}
\hline Concentration of PSAE & $\begin{array}{c}\text { Antioxidant content }(\mathrm{mmol} / \mathrm{L} \text { Trolox eq }) \pm \\
\text { standard deviation }\end{array}$ \\
\hline $0 \%(\mathrm{n}=3)$ & $3.51 \pm 0.02^{\mathrm{a}}$ \\
\hline $5 \%(\mathrm{n}=3)$ & $3.46 \pm 0.08^{\mathrm{a}}$ \\
\hline $10 \%(\mathrm{n}=3)$ & $3.38 \pm 0.09^{\mathrm{a}}$ \\
\hline $15 \%(\mathrm{n}=3)$ & $3.41 \pm 0.39^{\mathrm{a}}$ \\
\hline
\end{tabular}

* Equal letters in the same column means no significant statistic differences. All analysis were performed in triplicate.

The results of sensorial analysis are presented in Figure 1. Flavor, color, aroma and global aspects means did not show statistical differences. However, PSAE addition did not spoil most of the sensorial attributes of handmade beer.

Figure 1 - Sensorial analysis of handmade beer with Pecan Shell Aqueous Extract (PSAE) $(n=60)$.
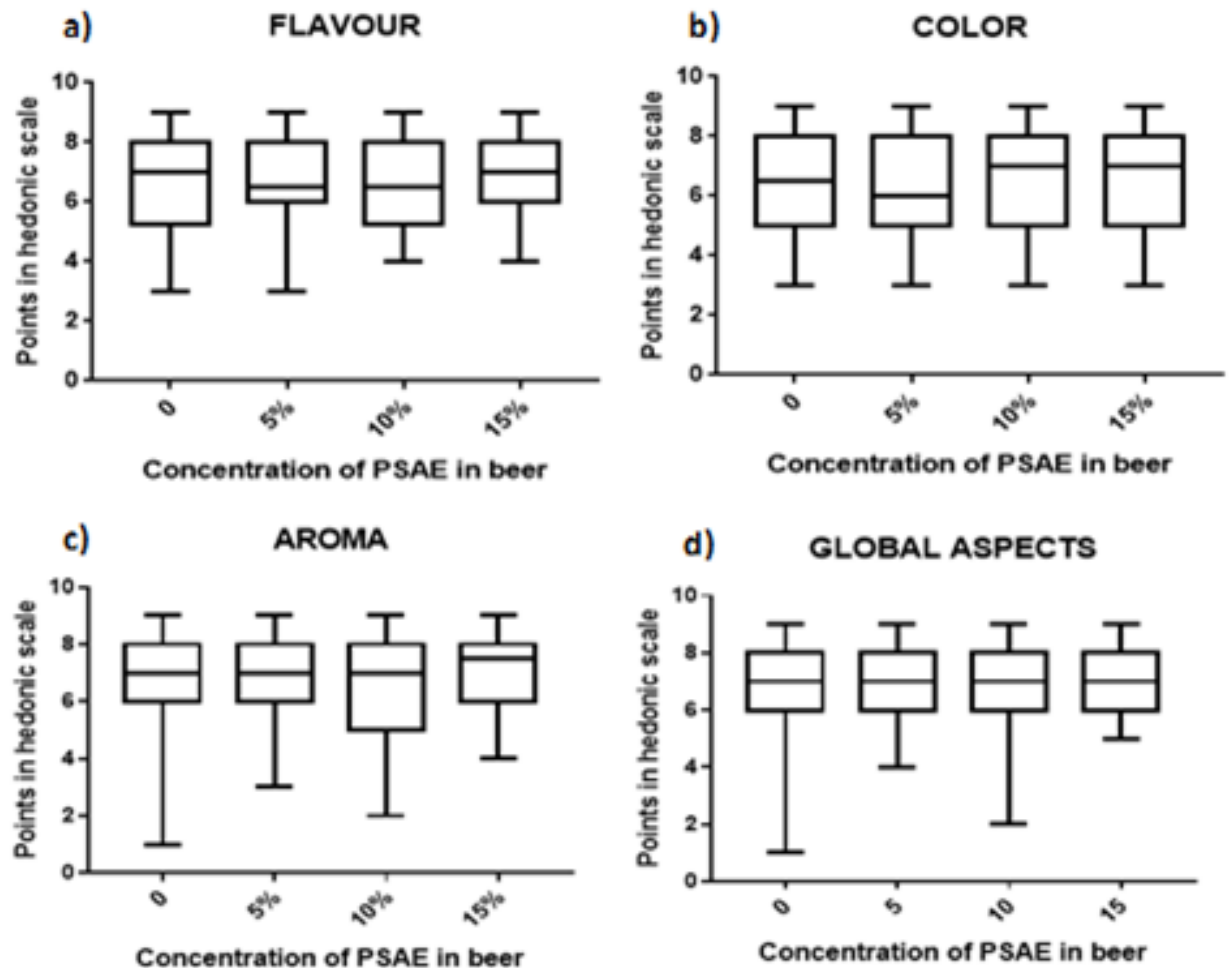
The "flavor" attribute, demonstrated in Figure 1-a), ranged between 3 and 9 points, but despite this variation, most participants evaluated the beer as 6 or higher on the hedonic scale. The beer formulation with water instead of PSAE obtained 8 points by 18 participants, and this was the most frequent value in the analysis. As for 5\% and $10 \%$ PSAE formulations, the most frequent grade was 6, while in $15 \%$ PSAE formulation, the attribute 8 was the most frequent registered, demonstrating that PSAE addition still provides a pleasant taste to the beer. An analysis performed by Magnuson et al. (2016) described the flavor of eight pecan nut cultivars and traced a unique profile for this nut. The pleasant taste reported by most participants in our study may be due to the composition of the pecan nutshell, which comprises flavonoids and terpenes, which bring a slightly bitter flavor to the beer (MAGNUSON et al., 2016).

The "color" attribute [Figure. 1-b)] showed that 0\% and 5\% PSAE beer pleased less the participants, with results of 6 and 5 points, respectively. However, the $10 \%$ and $15 \%$ PSAE beer had more grades 8 than other grades. This probably occurred due to the dark color added by PSAE, showing a "brownish" color, characteristic of the Oatmeal Stout beer style, an attribute expected by the consumers (DE KEUKELEIRC, 2000; PRADO et al., 2013).

The "aroma" attribute had good evaluations by our participants, as represented in Figure 1-c), even considering all concentrations of PSAE. Most classifications were 7 or 8 points on the hedonic scale. The $15 \%$ PSAE beer pleased more the participants, despite the higher concentration of pecan nutshell extract. An amount of $70 \%$ of the participants classified this beer as 9,8 , or 7 , a high classification value.

Global aspects are represented in Figure 1-d), where the overall beer sensorial analysis is represented. The data shows good acceptability by participants, since all beers scored 8, except for the 5\% PSAE beer, which scored 6 on the hedonic scale. This data shows that the product pleased the participants.

\section{CONCLUSIONS}

It was demonstrated that the pecan nutshell used in this study is a viable and alternative source of adjuncts to be used in handmade beer elaboration. Once pecan nutshell is a byproduct of pecan nut processing, its use will not increase the final value of the product. 
The beer brewed in this study was within the standard parameters found in literature, and the chosen process revealed a sharp fermentation, with medium alcohol volume and low sweet taste, characteristic of the Oatmeal Stout style. The physicochemical parameters were not significantly modified even with the increase of pecan nutshell extract (PSAE) concentration.

Although the addition of PSAE did not show an increase of antioxidant activity in beer, the sensorial analysis results demonstrated good acceptability by the consumers, which can be explored to improve the PSAE incorporation to the formula and the antioxidant activity, as well as sensorial aspects.

\section{ACKNOWLEGMENTS}

The authors would like to thank Divinut Industry - Cachoeira do Sul/RS, Brasil that provided pecan shells.

T.O.S. thanks Fundação Araucária de Apoio ao Desenvolvimento Científico e Tecnológico of Paraná State for its fellowship.

\section{REFERÊNCIAS}

ATANASOV, A. G. et al. Pecan nuts: A review of reported bioactivities and health effectsTrends in Food Science and Technology, v. 71, p. 246-257, 2018.

BENVEGNÚ, D. M. et al. Aqueous extract of pecan nut shell (Carya illinoensis [Wangenh.] K. Koch) exerts protection against oxidative damage induced by cyclophosphamide in rat testis. Journal of Environmental Pathology, Toxicology and Oncology, v. 32, n. 4, 2013.

BENVEGNÚ, D. M. et al. Protective effects of a by-product of the pecan nut industry (Carya illinoensis) on the toxicity induced by cyclophosphamide in rats Carya illinoensis protects against cyclophosphamide- induced toxicity. Journal of Environmental Pathology, Toxicology and Oncology, v. 29, n. 3, 2010.

BJCP. Beer Judge Certification Program. Style Guidelines, 2015.

BOTELHO, B. G. Perfil e teores de aminas bioativas e características físicoquímicas em cervejas. Belo Horizonte - MG, 2006.

BRASIL, R. F. DO. Sistema de Controle de Produção de Bebidas - SICOBE. [s.l: s.n.]. 
COMPTON, J. Beer quality and taste methodology. In: BRODERICK, H. M. (Ed.). . The practical brewer: a manual for the brewing industry. $2^{\mathrm{a}}$ ed. [s.l.] Madison, 1978. p. 288-308.

DAI, J.; MUMPER, R. J. Plant phenolics: Extraction, analysis and their antioxidant and anticancer propertiesMolecules, v. 15, n. 10, p. 7313-7352, 2010.

DE KEUKELEIRC, D. Fundamentals of beer and hop chemistry. Quimica Nova, v. 23, p. 108-112, 2000.

DE LA ROSA, L. A.; ALVAREZ-PARRILLA, E.; SHAHIDI, F. Phenolic compounds and antioxidant activity of kernels and shells of Mexican pecan (Carya illinoinensis). Journal of Agricultural and Food Chemistry, v. 59, n. 1, p. 152-162, 2011.

DUTCOSKY, Silvia Deboni. Análise sensorial de alimentos. In: Análise sensorial de alimentos. 2011. p. 426-426.

FREITAS, G. L. DE et al. Avaliação da atividade antioxidante de diferentes cervejas aplicando os métodos ABTS e DPPH. Alimentos e Nutrição Araraquara, v. 17, n. 3, p. 303-307, 2009.

HILBIG, J. et al. Aqueous extract from pecan nut [Carya illinoinensis (Wangenh) C. Koch] shell show activity against breast cancer cell line MCF-7 and Ehrlich ascites tumor in Balb-C mice. Journal of Ethnopharmacology, v. 211, p. 256-266, 2018.

HOLT, S. et al. Bioflavoring by non-conventional yeasts in sequential beer fermentations. Food Microbiology, v. 72, p. 55-66, 2018.

HUMIA, B. V. et al. Beer molecules and its sensory and biological properties: A review. Molecules, v. 24, n. 8, p. 1568, 2019.

KOREN, D. et al. Study of antioxidant activity during the malting and brewing process. Journal of Food Science and Technology, v. 56, n. 8, p. 3801-3809, 2019.

MAGNUSON, S. M. et al. A Comparison of Flavor Differences between Pecan Cultivars in Raw and Roasted Forms. Journal of Food Science, v. 81, n. 5, p. S1243S1253, 2016.

MARTINEZ-GOMEZ, A.; CABALLERO, I.; BLANCO, C. A. Phenols and melanoidins as natural antioxidants in beer. Structure, reactivity and antioxidant activityBiomolecules, v. 10, n. 3, p. 400, 2020.

MATHIAS, T. R. S.; MELLO, P. P. M.; SERVULO, E. F. C. Solid wastes in brewing process: A review. Journal of Brewing and Distilling, v. 5, n. 1, p. 1-9, 2014.

PORTO, L. C. S. et al. Evaluation of acute and subacute toxicity and mutagenic activity of the aqueous extract of pecan shells [Carya illinoinensis (Wangenh.) K. Koch]. Food and Chemical Toxicology, v. 59, p. 579-585, 2013.

PRADO, A. C. P. DO et al. Relationship between antioxidant properties and chemical composition of the oil and the shell of pecan nuts [Caryaillinoinensis (Wangenh) C.

Koch]. Industrial Crops and Products, v. 45, p. 64-73, 2013.

REINOLD, M. R. Manual Prático de Cervejaria. $1^{\text {a }}$ ed. São Paulo: Aden, 1997. 
ROBERTSON, J. A. et al. Profiling brewers' spent grain for composition and microbial ecology at the site of production. LWT - Food Science and Technology, v. 43, n. 6, p. 890-896, 2010.

SIQUEIRA, P. B.; BOLINI, H. M. A.; MACEDO, G. A. O processo de fabricação da cerveja e seus efeitos na presença de polifenóis. Alimentos e Nutrição Araraquara, v. 19, n. 4, p. 491-498, 2009.

TAFULO, P. A. R. et al. Control and comparison of the antioxidant capacity of beers. Food Research International, v. 43, n. 6, p. 1702-1709, 2010.

TECHAKRIENGKRAI, I. et al. Relationships of sensory bitterness in lager beers to Iso- $\alpha$-acid contents. Journal of the Institute of Brewing, v. 110, n. 1, p. 51-56, 2004.

VILLARREAL-LOZOYA, J. E.; LOMBARDINI, L.; CISNEROS-ZEVALLOS, L. Phytochemical constituents and antioxidant capacity of different pecan [Carya illinoinensis (Wangenh.) K. Koch] cultivars. Food Chemistry, v. 102, n. 4, p. 12411249, 2007.

WORLEY, Ray E. Pecan physiology and composition. In: Pecan technology. Springer, Dordrecht, 1994. p. 39-48.

ZENEBON, O.; PASCUET, N. S.; TIGLEA, P. Instituto Adolfo Lutz, Métodos físicoquímicos para análise de alimentos. Núcleo de Informação e Tecnologia, São Paulo, 2008.

ZUPPARDO, B. Uso da goma Oenogum para a estabilização coloidal e de espuma em cerveja. Piracicaba: Universidade de São Paulo, 2010. 